\title{
Phytoplankton dynamics in a drinking water catchment zone at the Amazon River mouth
}

\author{
Natalina Borges da Silva' (D), Luis Mauricio Abdon da Silva² (1), Luís Roberto Takiyama² (D), \\ Mariano Araújo Bernardino Rocha ${ }^{3}$ and Elane Domênica Cunha de Oliveira ${ }^{2 *}$
}

Received: November 13, 2020

Accepted: April 16, 2021

\begin{abstract}
Phytoplankton is formed by photosynthesizing microorganisms that act as primary producers in distinct water bodies. These include microalgae and cyanobacteria. It is essential to know the phytoplankton in water catchment areas intended for drinking water treatment once their excessive density may result in problems, such as taste and odor in the water, toxin production, filter clogging, and other damages. This study investigated the phytoplankton dynamics and the environmental factors that may influence phytoplankton density in the drinking water catchment zone of Macapá, a city located on the Amazon River mouth. The sampling was carried out monthly from April/2015 to March/2016. The study reports the first detailed information on the phytoplankton in the study area since previously published studies regarded only cyanobacteria. The species Limnothrix planctonica and Aulacoseira granulata may substantially influence the water treatment due to their great abundance in the study area, especially in July and November, when their density peaks occur, respectively. Nevertheless, Aulacoseira granulata is the primary constituent of the phytoplankton biovolume. This study provides biological and sanitary information to guide public administration towards improving the quality and safety of water supply services, and also to increase the biodiversity knowledge of Amazonian phytoplankton.
\end{abstract}

Keywords: Amazon River, cyanobacteria, Macapá, microalgae, water supply, water treatment

\section{Introduction}

Phytoplankton comprises photosynthetic microorganisms-microalgae and cyanobacteria-adapted to live partly or continuously in open water (Chorus \& Bartram 1999; Reynolds 2006). These organisms are responsible for the oxygenation of aquatic ecosystems, where they act as the primary producer of organic carbon (Reynolds 2006).

Phytoplankton populations may increase rapidly (bloom) as a consequence of eutrophication and pollution of the water body. High phytoplankton densities in the water supply impair the water quality since these organisms may cause several problems for drinking water treatment, such as the production of toxins, taste and odor compounds, trihalomethanes, clogging of filters, and reduction of efficiency to produce finished water (Di Bernardo 1995; Chorus \& Bartram 1999; Ewerts et al. 2013; Oliver \& Ribeiro, 2014).

Some species from the cyanobacteria, diatoms, chlorophytes, chrysophytes, rhodophytes, and dinoflagellates

1 Polícia Tecnico-Científica do Amapá, 68908-575, Macapá, AP, Brazil

2 Instituto Pesquisas Científicas e Tecnológicas do Estado do Amapá, 68903-419, Macapá, AP, Brazil

3 Universidade do Estado do Amapá, 68900-070, Macapá, AP, Brazil

* Corresponding author: elanedsc@yahoo.com.br 
are known to cause problems to water treatment plants (Watson 2009; Ewerts et al. 2013; Niiyama et al. 2016). In the case of the production of taste and odor compounds, some of the principal causes that make difficult the source-tracking of these compounds include species misidentification (Watson \& Jüttner 2019). Because of these issues, it is essential to know the phytoplankton composition and density to prevent or quickly solve future trouble related to water treatment concerns.

This study was conducted in Macapá, a city located at the Amazon River mouth, whose waters are the primary source of water supply in town. This estuary area has multiple uses like the loading/unloading of cargo and passengers, sports, bathing, fishing, and leisure (Oliveira et al. 2019a). Besides that, there is an occasional and diffuse discharge of effluents into the river, which provides nutrients for phytoplankton population growth (Bastos et al. 2009).

The purpose of this study is to investigate the phytoplankton composition, density, and biovolume, and the environmental factors that may have an influence on phytoplankton density in the drinking water catchment zone of Macapá. The results intend to guide public administration towards improving the quality and safety of water provision services.

\section{Materials and methods}

\section{Study area and sampling procedures}

The samples were collected in the city of Macapá, at the Company of Water Supply and Sewage of Amapá (CAESA), at the raw water intake point, which is situated approximately 500 meters from the Amazon River bank (Fig. 1), nearby the city downtown. Macapá is a city located in the Northern Channel of the Amazon River in the State of Amapá, Brazilian Amazonia.

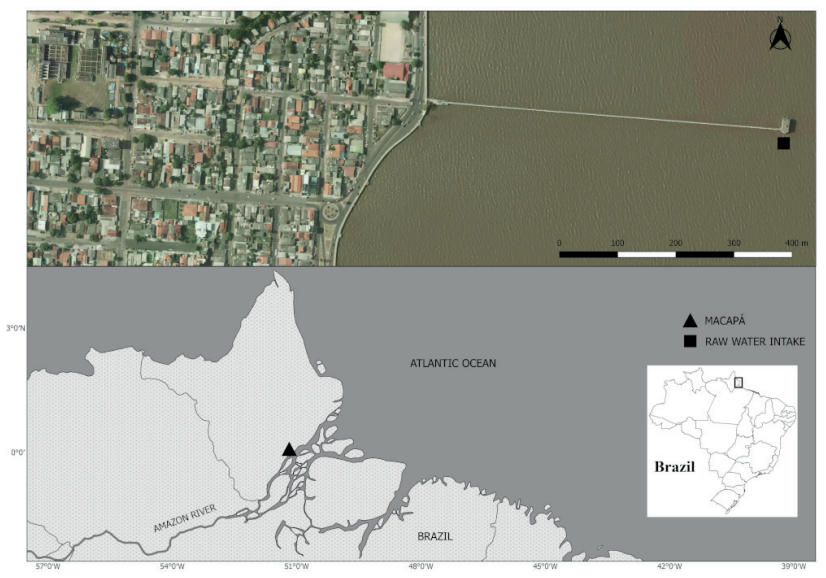

Figure 1. Study area: water intake point for water supply in the municipality of Macapá, State of Amapá.
Sampling occurred monthly from April/2015 to March/2016 during a tidal cycle (13 hours). We collected material for qualitative and quantitative studies of phytoplankton as well as physicochemical analysis of the water.

\section{Environmental variables}

The environmental data measured were turbidity, suspended solids, precipitation, insolation, radiation, water temperature, water transparency, dissolved oxygen, nutrients (nitrate, nitrite, ammonia, phosphorus, and phosphate), and $\mathrm{pH}$ (Tab. 1).

\section{Qualitative analysis of phytoplankton}

We collected the qualitative analysis samples every two hours, using the horizontal and simultaneous dragging of two plankton nets- $20 \mu \mathrm{m}$ and $64 \mu \mathrm{m}$ mesh opening. In one day of sampling work, we provided seven samples for each plankton net used. In the laboratory, we took aliquots from the $20 \mu \mathrm{m}$ mesh samples and combined them into a single representative sample; we did the same with the $64 \mu \mathrm{m}$ mesh samples. This technique, known as composite sampling (Brandão et al. 2011), allowed the formation of a monthly qualitative sample for each plankton net employed, which reduced the sampling effort and shortened the analysis time. Qualitative samples were preserved with Transeau's solution (Bicudo \& Menezes 2006).

We identified the taxa under standard light microscopy with the aid of specialized bibliography (Prescott et al. 1977; 1982; Anagnostidis \& Komárek 1986; 1988; Komárek \& Anagnostidis 1999; Godinho 2005; Bicudo \& Menezes 2006; Sant'Anna et al. 2006; Faustino 2006; Godinho 2009) and recent taxonomic papers describing new genera, examining ten slides for each sample. Richness was calculated as the number of species founded in the slides.

\section{Phytoplankton counting}

For phytoplankton counting, we collected samples monthly at the raw water intake during high tide and stored them in a $1 \mathrm{~L}$ amber glass bottle, preserved with $8 \mathrm{~mL}$ of Lugol's solution. The quantitative analyzes were performed using the Utermöhl sedimentation method (Utermöhl 1958) in $5 \mathrm{~mL}$ Utermöhl chambers, visualized in an inverted microscope under a 400x magnification. After sedimentation, we counted the organisms throughout the whole chamber base. To obtain the phytoplankton density (organisms per milliliter), the number of organisms was multiplied by $0.2(1 / 5=$ one whole base of the chamber divided by the decanted volume $5 \mathrm{~mL}$ ) (APHA 2010; Cetesb 2012). To determine the abundant and dominant species, we used the Lobo \& Leighton (1986) criterion, where abundant species are those whose number of individuals is higher than the average value of the total number of individuals per species in a sample. The dominant species are those with $\geq 50 \%$ of the total number of individuals in the sample. 


\section{Average and total biovolume}

The average biovolume $\left(\mu \mathrm{m}^{3}\right)$ was determined from measurements of 10 to 30 individuals of each species taking into account the simplest geometric configuration (sphere, cone, cylinder, prism, ellipsoid, spheroid, and cuboid) that best suited for phytoplankton organisms' shapes, disregarding mucilages or arrows (Hillebrand et al. 1999). As a means to obtain the total biovolume $\left(\mu \mathrm{m}^{3} \mathrm{~mL}^{-1}\right)$, we multiplied the average biovolume of the individuals by their density.

\section{Statistical analysis}

A Canonical Correspondence Analysis (CCA) was used to infer the relationship between abiotic variables and phytoplankton species. To perform the CCA, we used data on the relative abundance of phytoplankton. Species with a density of $\leq 10 \%$ of the total density or frequency of occurrence $<1 / 5$ of the most common species were excluded to reduce trends caused by rare species. Then, we transformed the biological and environmental data into $\ln$ $(x+1)$ to standardize distribution and reduce the effects of the most abundant species. After that, we selected physical and chemical parameters with the ordistep function of the R 3.4.3 software (R Development Core Team 2017). Subsequently, we calculated the inflation factor (VIF) to exclude multicollinear variables, eliminating the variables with VIF $\geq 15$ (Oksanen 2012). This selection aimed at removing irrelevant explanatory variables in the analysis, highly correlated factors, and variables with relatively little variation (Ter Braak \& Verdonschot 1995).

After the screening above, we performed CCA with four environmental variables (suspended solids, rainfall, ammonia $\left(\mathrm{NH}_{4}\right)$, and dissolved oxygen) and the most common phytoplankton species detected in the study.

\section{Results}

\section{Environmental aspects}

The characterization of the environmental parameters is summarized in Table 2. Throughout the study, the Amazon River turbidity presented an average value of 49.30 NTU (range $=19.80-122 \mathrm{NTU}$ ), and suspended solids averaged 52.85 mg. $L^{-1}$ (range $\left.=24.70-119.20 \mathrm{mg} . \mathrm{L}^{-1}\right)$. The water transparency varied from $12.50 \mathrm{~cm}$ (rainy season) to $36.50 \mathrm{~cm}$ (dry period).

Regarding monthly precipitation in Macapá city, the wettest months were April 2015 (584.50 mm) and February $2016(528.20 \mathrm{~mm})$. It is noteworthy that there was no rainfall in September, October, and November 2015 (dry period of the region). The average monthly insolation in Macapá ranged from 3.30 to 9.79 hours, and the months between August-December 2015 presented the highest insolation. Regarding irradiation, on the sampling day, there was a variation between 86.60 to 312.30 W.m. ${ }^{-2}$, with an average of $236.82 \mathrm{~W} \cdot \mathrm{m}^{-2}$.

Table 1. Measurement units of the physical and chemical parameters, methods, analysis equipment, and database.

\begin{tabular}{|c|c|c|c|}
\hline & Parameter & Unit & Method / Equipment / Database \\
\hline \multirow{8}{*}{ Physical } & Turbidity & NTU & Horiba multi-parameter probe \\
\hline & Suspended solids & $\mathrm{mg} \mathrm{L}^{-1}$ & Gravimetric analysis (APHA 2012) \\
\hline & Rainfall & $\mathrm{Mm}$ & INMET \\
\hline & Insolation & Hour & INPE \\
\hline & Radiation & $\mathrm{W} \mathrm{m}{ }^{-2}$ & INP \\
\hline & Water temperature & ${ }^{\circ} \mathrm{C}$ & Horiba multi-parameter probe \\
\hline & Water transparency & $\mathrm{Cm}$ & Secchi Disk \\
\hline & Dissolved Oxygen (DO) & $\mathrm{mg} \mathrm{L}^{-1}$ & YSI 550 A DO (Dissolved oxygen meter) \\
\hline \multirow{6}{*}{ Chemical } & Nitrate $\left(\mathrm{NO}_{3}\right)$ & $\mathrm{mg} \mathrm{L}^{-1}$ & Cadmium reduction (APHA 2012) \\
\hline & Nitrite $\left(\mathrm{NO}_{2}\right)$ & $\mathrm{mg} \mathrm{L}^{-1}$ & Diazotization (APHA 2012) \\
\hline & Ammonia $\left(\mathrm{NH}_{3}\right)$ & $\mathrm{mg} \mathrm{L}^{-1}$ & Phenate method (APHA 2012) \\
\hline & Phosphorus (P) & $\mathrm{mg} \mathrm{L}^{-1}$ & Molybdenum blue (APHA 2012) \\
\hline & Phosphate $\left(\mathrm{PO}^{3-}\right)$ & $\mathrm{mg} \mathrm{L}^{-1}$ & Molybdenum blue (APHA 2012) \\
\hline & Water $\mathrm{pH}$ measurements & - & Orion Star A121 pH meters \\
\hline
\end{tabular}

Table 2. Minimum, maximum, average and standard deviation values of environmental variables. Turb - Turbidity (NTU); SS Suspended solids (mg L-1); Rain - Rainfall (mm); Ins - Insolation (hours); Irrad - Irradiation (W m-2); W T - Water Temperature $\left({ }^{\circ} \mathrm{C}\right)$; Transp - Water transparency (cm); DO - Dissolved oxygen; NO3 - Nitrate (mg L-1), NO2 - Nitrite (mg L-1); NH3 - Ammonia (mg L-1); P - Phosphorus (mg L-1); PO43- - Phosphate (mg L-1); pH - Hydrogen potential.

\begin{tabular}{|c|c|c|c|c|c|c|c|c|c|c|c|c|c|c|}
\hline & Turb & SS & Rain & Ins & Irrad & $W T$ & Transp & DO & $\mathrm{NO}_{3}$ & $\mathrm{NO}_{2}$ & $\mathrm{NH}_{3}$ & $\mathbf{P}$ & $\mathrm{PO}_{4}^{3 .}$ & pH \\
\hline Minimum & 19.80 & 24.77 & 0.00 & 3.30 & 86.60 & 28.12 & 12.50 & 6.60 & 0.00 & 0.02 & 0.00 & 0.00 & 0.00 & 6.00 \\
\hline Maximum & 122.00 & 119.2 & 584.50 & 9.79 & 312.30 & 30.27 & 36.50 & 7.79 & 0.93 & 0.07 & 0.20 & 0.12 & 0.38 & 7.20 \\
\hline Average & 49.30 & 52.85 & 213.66 & 7.05 & 236.82 & 29.60 & 26.21 & 7.16 & 0.46 & 0.04 & 0.06 & 0.03 & 0.08 & 6.57 \\
\hline Standard Deviation & 37.23 & 33.52 & 221.87 & 2.33 & 76.23 & 0.66 & 8.75 & 0.40 & 0.38 & 0.02 & 0.06 & 0.03 & 0.11 & 0.28 \\
\hline
\end{tabular}


The average water temperature in the Amazon River was $29.6^{\circ} \mathrm{C}$ (range $\left.=28.12-30.27^{\circ} \mathrm{C}\right)$; dissolved oxygen ranged from $6.60 \mathrm{mg} \cdot \mathrm{L}^{-1}$ to $7.79 \mathrm{mg} \mathrm{L}^{-1}$; and $\mathrm{pH}$ values ranged from 6.0 (slightly acidic) to 7.2 (neutral) (Tab. 2).

Regarding nutrients, nitrate values ranged from 0.08 to $0.93 \mathrm{mg} . \mathrm{L}^{-1}$; nitrite from 0.02 to $0.07 \mathrm{mg} . \mathrm{L}^{-1}$; ammonia from 0.01 to $0.20 \mathrm{mg} . \mathrm{L}^{-1}$; phosphorus from 0.01 to 0.04 $\mathrm{mg} . \mathrm{L}^{-1}$; and phosphate from 0.02 to $0.38 \mathrm{mg} . \mathrm{L}^{-1}$.

\section{Qualitative analysis of phytoplankton}

Species composition analysis allowed the identification of 180 taxa distributed in six divisions: Cyanobacteria, Chlorophyta, Bacillariophyta, Euglenophyta, Charophyta, and Ochrophyta (Tab. S1 in supplementary material). Charophyta was the most expressive group, presenting the highest richness values $(S=73)$. Species richness ranged from 59 to 114 taxa over the study period, with April and September 2015 showing the highest richness values, 114 and 110, respectively (Fig. 2).

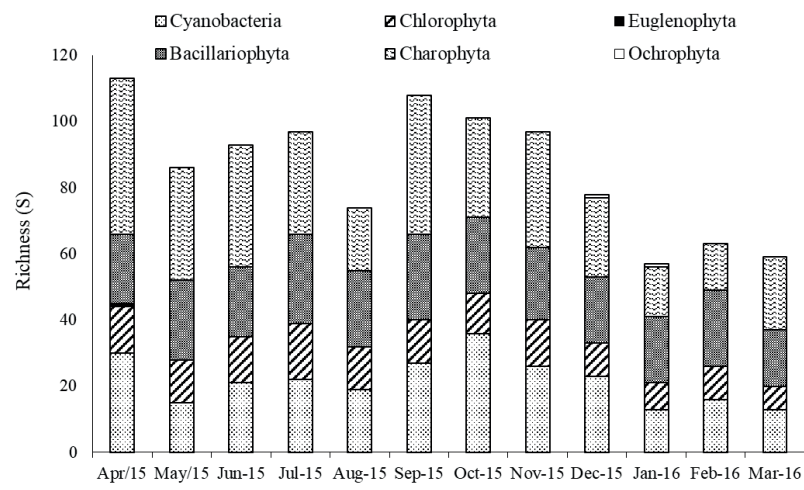

Figure 2. Richness by taxonomic division.

\section{Phytoplankton counting}

We identified forty-four taxa in the counting samples, belonging to Bacillariophyta, Charophyta, Chlorophyta, Cyanobacteria, and Euglenophyta. Diatoms presented higher density throughout the study except in July when Cyanobacteria were the group with the highest density values.

The months of highest phytoplankton density were July (72.6 org. $\mathrm{mL}^{-1}$ ) and November 2015 (117 org. $\mathrm{mL}^{-1}$ ), when there were peaks of cyanobacteria and diatoms, respectively. In July 2015, the Cyanobacteria density was 44.4 org. $\mathrm{mL}^{-1}$ ( $61.2 \%$ of total period density), and in November 2015, the Bacillariophyta density was 109.6 org.mL $L^{-1}(93.7 \%$ of total month density) (Fig. 3).

Figure 4 shows a comparison between the total phytoplankton density and that of Aulacoseira granulata and Limnothrix planctonica. The organisms with the highest density values were: A. granulata (Heterokontophyta) and L. planctonica (Cyanophyta) (Fig. 5). The high density of these two species resulted in the dominance alternation of Bacillariophyta and Cyanobacteria.

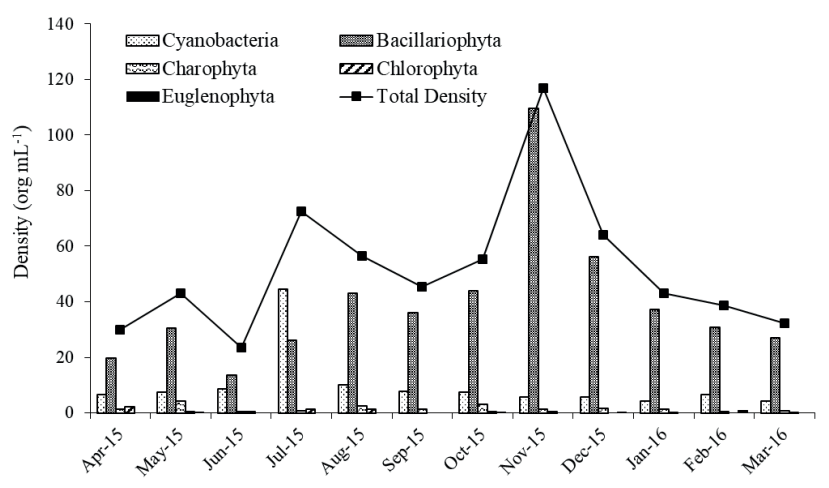

Figure 3. Phytoplankton density by taxonomic division in the Amazon River from April 2015 to March 2016.

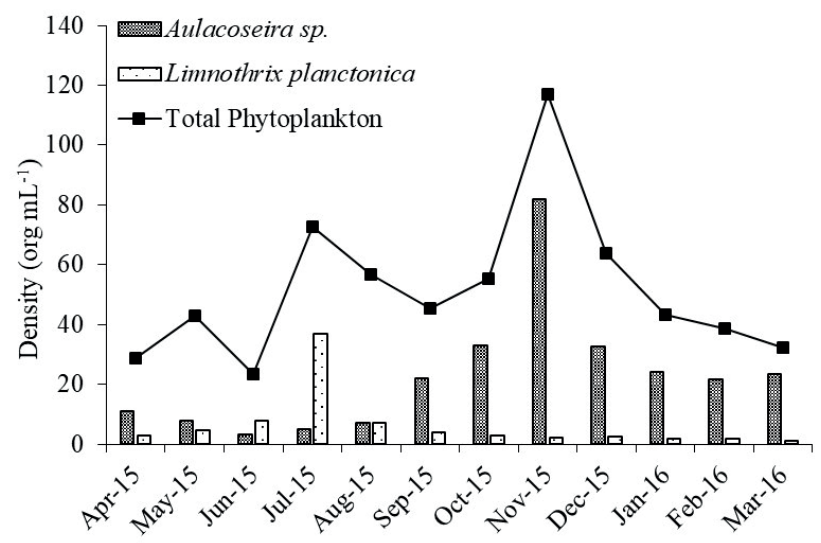

Figure 4. Comparison between the total phytoplankton density and that of the most abundant species.

Aulacoseira granulata and Limnothrix planctonica were dominant species, while Alkalinema pantanalense, Leptolyngbya sp., L. planctonica, Closterium acutum, Ulnaria sp., Placoneis sp., A. granulata e Actinocyclus sp. were considered abundant (Figs. 5 and 6).

\section{Determination of total and average biovolume}

Bacillariophyta species showed the highest biovolume values (Tab. 3), suggesting that the phytoplankton in the study area is essentially formed by diatoms. Thus, whereas the density results indicated significant participation of Cyanobacteria, the biovolume determination revealed that Bacillariophyta had a greater number of large species than the other groups.

The monthly phytoplankton biovolume ranged from $53075.9 \mu^{3} \mathrm{~mL}^{-1}$ in June/2015 to $774438.6 \mu^{3} \mathrm{~mL}^{-1}$ in November/2015. This peak was influenced by the species Aulacoseira granulata (Bacillariophyta). The pattern of phytoplankton density results was different from the biovolume. For density, two months were remarkable (July/15 and November/15) with emphasis on the densities of Limnothrix planctonica and A. granulata; however, regarding biovolume, A. granulata stands out for its high dimensions. In this sense, diatoms constitute the phytoplankton in the 

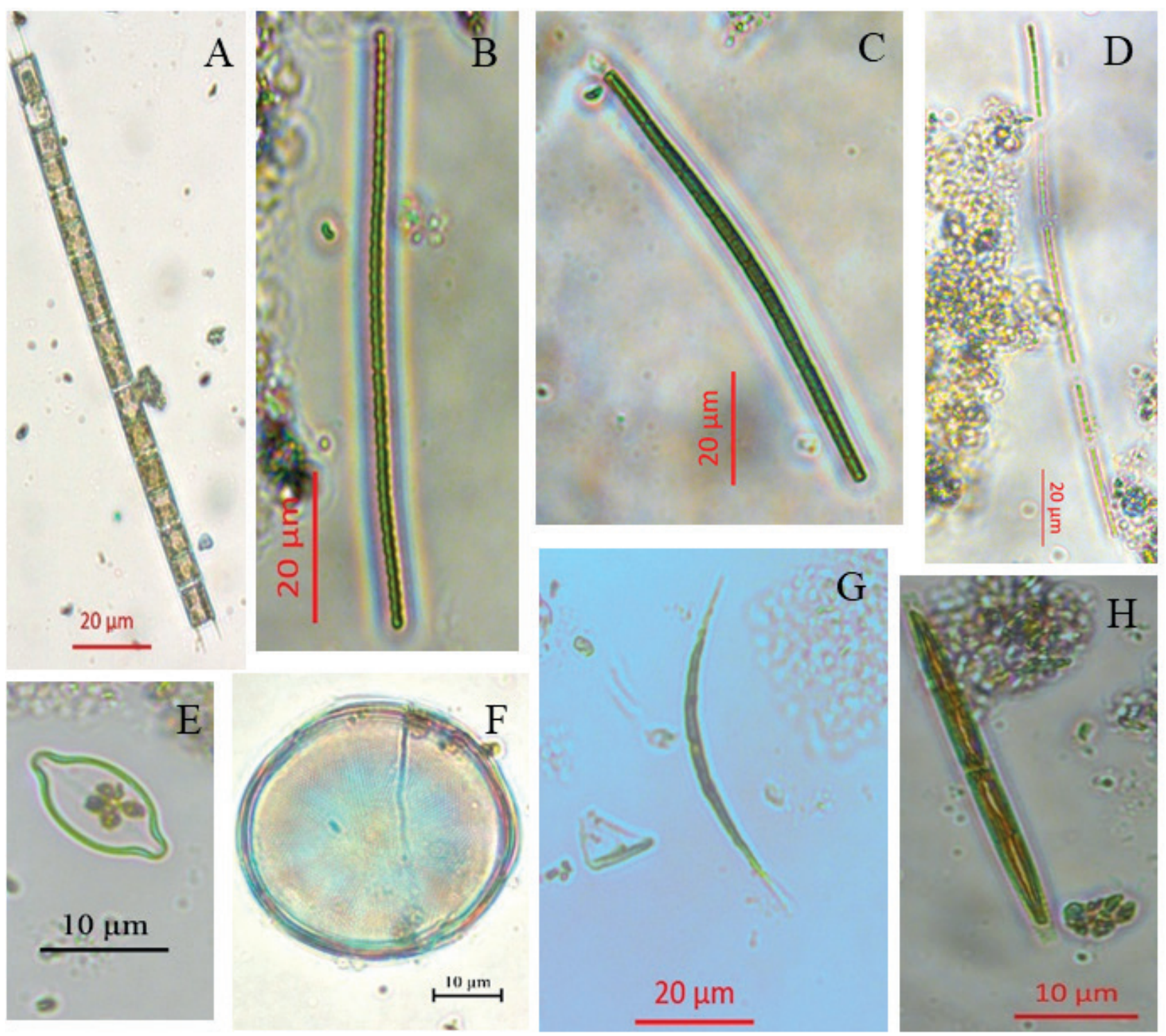

Figure 5. Abundant and dominant species: (A) Aulacoseira granulata, (B) Alkalinema pantanalense, (C) Limnothrix planctonica, (D) Leptolyngbya sp., (E) Placoneis sp., (F) Actinocyclus sp., (G) Closterium acutum, and (H) Ulnaria sp.

study area, especially Aulacoseira granulata (Fig. 5A). Figure 7 shows the significant participation of this species in total monthly biovolume.

\section{Influence of environmental factors on phytoplankton}

To perform canonical correspondence analysis (CCA), a previous statistical analysis (forward selection) chose the environmental variables that had more influence on the abundance of phytoplankton from a matrix of 14 environmental variables (Tab. 2): suspended solids, rainfall, ammonia $\left(\mathrm{NH}_{4}\right)$, and dissolved oxygen. We used these four variables to perform the CCA with the most abundant and frequent phytoplankton taxa: Limnothrix planctonica, Alkalinema pantanalense, Leptolyngbya sp., Closterium acutum, Actinocyclus sp., Aulacoseira granulata, Pinullaria sp., Placoneis sp., Ulnaria sp., and Surirella guatimalensis.

The axes 1 and 2 accounted for $96.03 \%$ of the variance (axis 1: $81.47 \%$; axis 2: $14.56 \%$ ). We evaluated the significance of the ordination axes and the environmental indicators using the Monte Carlo permutation test (999 randomizations).

During the study period, two environmental factors greatly influenced the species distribution: suspended solids and ammonia. Suspended solids strongly influenced the abundance of Leptolyngbya sp. and Aulacoseira granulata, with $A$. granulata being more abundant in November. Limnothrix planctonica and Alkalinema pantanalense showed ammonia as the determining factor and occurred in greater densities in June and July, a time when the suspended solids were lower (Fig. 8). 


\section{Phytoplankton dynamics in a drinking water catchment zone at the Amazon River mouth}

\section{Discussion}

Concerning the physicochemical parameters, the Amazon River presents typical whitewater river characteristics: nearneutral $\mathrm{pH}$, turbid waters rich in dissolved and suspended sediments, electrical conductivity between $40-100 \mu \mathrm{S} . \mathrm{cm}^{-1}$, and low transparency (Sioli 1984; Junk et al. 2011).
The qualitative analysis clearly shows the great richness of species encountered in the intake point $(S=180)$. This inventory may guide the drinking water treatment management in the case of need to identify causes (precursors) of taste and odor compounds, since the predominant species in the area may not necessarily be the main source of the odor (Otten et al. 2016; Chong et al. 2018; Watson \& Jüttner 2019). Besides, the qualitative

Table 3. Amazon River phytoplankton average biovolume in the study area CYAN - Cyanobacteria; CHLO - Chlorophyta; CHARCharophyta; BACI - Bacillariophyta; EUGL - Euglenophyta; GS - Geometric Shape; AB- Average Biovolume $\left(\mu \mathrm{m}^{3}\right)$.

\begin{tabular}{|c|c|c|c|}
\hline Division & Taxon & GS & $A B\left(\mu m^{3}\right)$ \\
\hline CYAN & Limnothrix planctonica & Cylinder & 219.71 \\
\hline CYAN & Alkalinema pantanalense & Cylinder & 99.06 \\
\hline CYAN & Leptolyngbya sp. & Cylinder & 73.43 \\
\hline CYAN & Pseudanabaena sp. & Cylinder & 240.18 \\
\hline CYAN & Anabaena sp. & Cylinder & 2041.99 \\
\hline CYAN & Dolichospermum sp. & Cylinder & 4662.17 \\
\hline CYAN & Geitlerinema_splendidum & Cylinder & 8661.33 \\
\hline CYAN & Cephalothrix sp. & Cylinder & 10458.16 \\
\hline CYAN & Raphidiopsis sp. & Cylinder & 91.08 \\
\hline CYAN & Ciano sp. & Cylinder & 920.39 \\
\hline CHLO & Actinastrum sp. & Cylinder +2 Cones & 78.3 \\
\hline CHLO & Acutodesmus sp. & Cylinder +2 Cones & 375.5 \\
\hline CHLO & Ankistrodesmus sp. & Cylinder +2 Cones & 398 \\
\hline CHLO & Desmodesmus communis & Spheroid & 246.2 \\
\hline CHLO & Lacunastrum sp. & Cylinder & 1780 \\
\hline CHLO & Nephrocytium sp. & Ellipsoid & 2200 \\
\hline CHLO & Volvox sp. & Sphere & 900 \\
\hline CHLO & Eudorina elegans & Sphere & 932 \\
\hline CHLO & Mucidosphaerium pulchellum & Sphere & 310.9 \\
\hline CHLO & Mougeotia sp. & Cylinder & 2433.46 \\
\hline CHLO & Staurastrum quadrinotatum & 2 Truncated Cones & 764 \\
\hline CHLO & Staurastrum leptocladum & 2 Truncated Cones & 1029.62 \\
\hline CHLO & Scenedesmus acuminatus & Cylinder +2 Cones & 375 \\
\hline CHAR & Closterium acutum & 2 Cones & 1800 \\
\hline CHAR & Closterium gracile & 2 Cones & 200 \\
\hline CHAR & Closterium sp. & 2 Cones & 4500 \\
\hline CHAR & Closterium sp. & 2 Cones & 3800 \\
\hline CHAR & Closterium setaceum & 2 Cones & 2620 \\
\hline CHAR & Desmidium bailey & Cylinder & 11471.55 \\
\hline BACI & Actinocyclus sp. & Cylinder & 4200 \\
\hline BACI & Aulacoseira granulata & Cylinder & 8452.63 \\
\hline BACI & Eunotia flexuosa & Sickle-shaped Prism & 316.47 \\
\hline BACI & Fragillaria sp. & Cuboid & 397.5 \\
\hline BACI & Gyrosigma sp. & Parallelepiped & 1500 \\
\hline BACI & Pinullaria sp. & Rectangular prism & 7900 \\
\hline BACI & Placoneis sp. & Elliptic prism & 269.53 \\
\hline BACI & Ulnaria sp. & Cuboid & 400 \\
\hline BACI & Urosolenia longiseta & Cylinder & 92.15 \\
\hline BACI & Iconella obtusiuscula & Elliptic prism & 7500 \\
\hline BACI & Iconella grunowii & Elliptic prism & 4000 \\
\hline $\mathrm{BACI}$ & Iconella guatimalensis & Elliptic prism & 5500 \\
\hline $\mathrm{BACI}$ & Iconella linearis & Elliptic prism & 4800 \\
\hline BACI & Tabellaria sp. & Cuboid & 153.20 \\
\hline EUGL & Phacus sp. & Elliptic prism & 1852 \\
\hline
\end{tabular}

CYAN - Cyanobacteria; CHLO - Chlorophyta; CHAR- Charophyta; BACI - Bacillariophyta; EUGL - Euglenophyta; GS - Geometric Shape; $\mathrm{AB}-$ Average Biovolume $\left(\mu \mathrm{m}^{3}\right)$. 


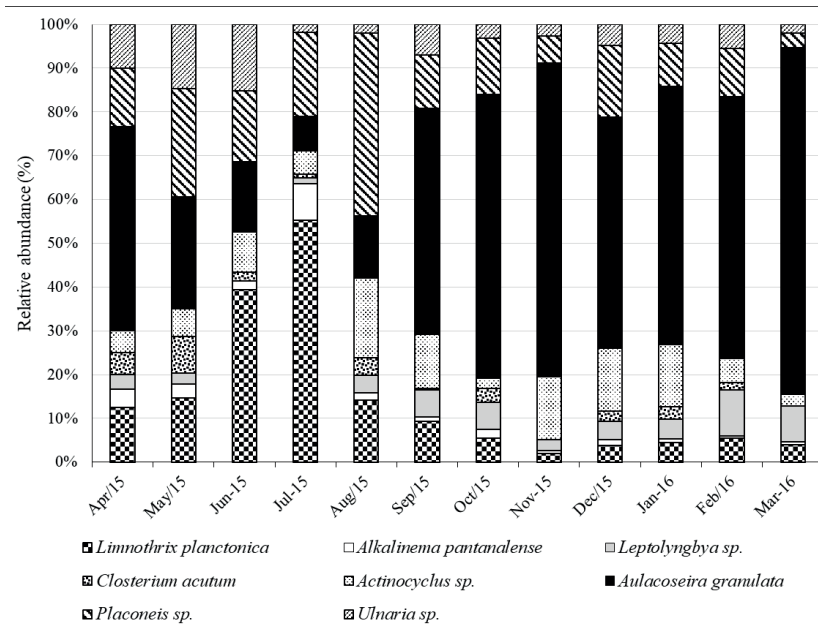

Figure 6. Abundant and dominant species at Macapá water intake point.

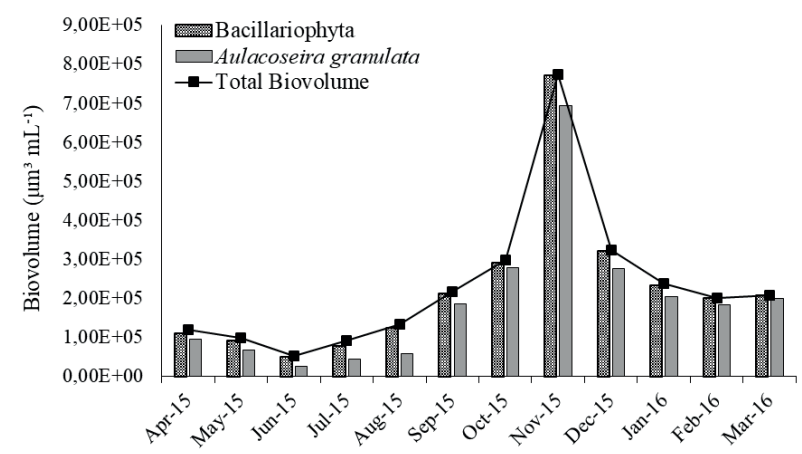

Figure 7. Total biovolume per month, and the contribution of Bacillariophyta and Aulacoseira granulata.

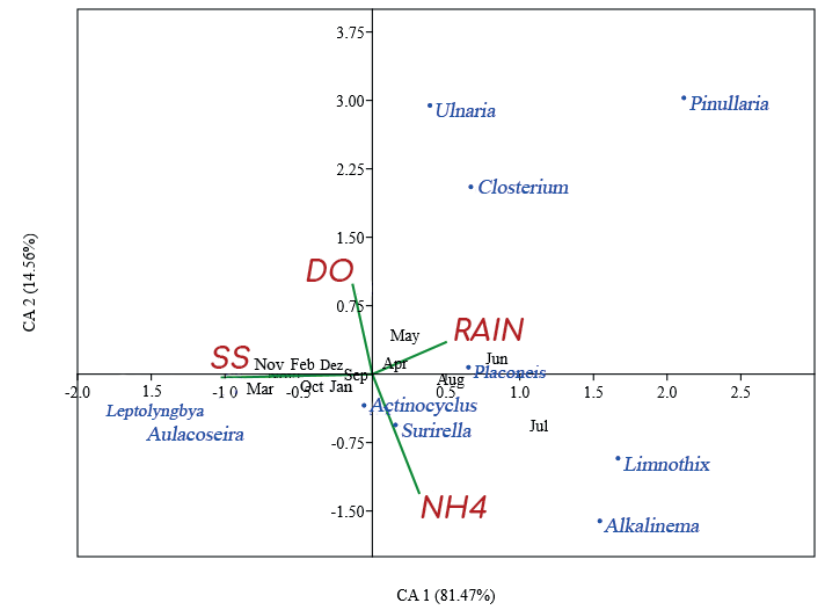

Figure 8. CCA ordination diagram (axes 1 and 2) applied to the matrix of selected biotic and abiotic variables. SS - Suspended solids; DO - Dissolved Oxygen; NH4 - Ammonia; RAIN - Rainfall; JAN - January; FEB - February; MAR - March; APR - April; MAY - May; JUN - June; JUL- July; AUG - August; SEP - September; OCT - October; NOV - November; DEC - December; Lepto_sp. - Leptolyngbya sp.; Aula_gra - Aulacoseira granulata; Acti_sp. - Actinocyclus sp .; Sur_guat - Surirella guatimalensis; Plac_sp. Placoneis sp .; Alka_pant - Alkalinema pantanalense. analysis will improve the knowledge of phytoplankton species in the Amazon River.

The quantitative analysis, on the other hand, does not consider all the species but detects the abundant and dominant species. This information is essential when considering problems like cyanotoxin production and filter clogging. The quantitative analysis shows that the Bacillariophyta and Cyanobacteria present the highest densities in the study area. Aulacoseira granulata (diatom) and Limnothrix planctonica (cyanobacteria) dominate the phytoplankton community in the area due to their body shape and physiological aspects greatly adapted to this turbulent and turbid environment (Reynolds et al. 1994; Nishimura et al. 2015; Oliveira et al. 2019a).

Aulacoseira granulata and Limnothrix planctonica are adapted to water column mixing conditions in shallow waters or mixed layers of 2-3m in thickness (Reynolds et al. 2002; Padisák et al. 2009; Brasil \& Huszar 2011). These conditions match the Amazon River characteristics, as it is turbulent and has no stratification (Sioli 1984). In the intake zone, all depths can be considered within the vertical mixing zone (approximately $3 \mathrm{~m}$ ) all over the year (Junk et al. 2014).

Another common feature that favors the dominance of A. granulata and L. planctonica is their filamentous shape, which implies that these taxa have a relatively high surface area. It makes them good light receptors adapted to grow in environments with low light penetration, such as the Amazon River (Naselli-Flores \& Barone 2007; Brasil \& Huszar 2011; Nishimura et al. 2015; Oliveira et al. 2019a).

Concerning the water treatment and supply, Aulacoseira granulata is one of the producers of fishy, rancid, oily, grassy, or cucumber odors (AWWA 2010; Watson \& Jüttner 2019). A. granulata is also problematic regarding coagulation, flocculation, and filtration in the water treatment process (Joh et al. 2011). Water treatment processes do not efficiently remove this species due to its long cylindrical shape, high surface to volume ratio $\left(S . V^{-1}\right)$, extensive superficial area, and higher surface contact with the surrounding media, which are all related to physical buoyancy or difficulties in settling (Padisák et al. 2003; Brasil \& Huszar 2011; Joh et al. 2011). Besides, this species also clogs the sand filters, leading to a need for repeated backwashing, thus limiting the production of clean water (Joh et al. 2011).

Limnothrix planctonica may produce the microcystin and limnothrixin toxins (Furtado et al. 2009; Bernard et al. 2011; Humpage et al. 2012; Whan 2015). L. planctonica strains were already isolated from the study area, but such strains showed no potential for microcystin production (Oliveira et al. 2019b). However, another study detected for the first time the presence of microcystin-LR in the Amazon River, at the same site, being L. planctonica the main suspect to have produced the toxin (Oliveira et al. 2019a).

Although the counting results show that the greatest densities belong to the groups Bacillariophyta and 
Cyanobacteria, the biovolume analysis reveals that the phytoplankton in the study area is primarily composed of diatoms, especially by the species Aulacoseira granulata. Diatoms constitute a relevant group in terms of algal biomass in the Amazon region (Moreira-Filho et al. 1974; Paiva et al. 2006; Monteiro et al. 2009; Silva et al. 2018).

The canonical correspondence analysis shows that suspended solids affect the composition of the phytoplankton community. In this respect, Aulacoseira granulata and Leptolyngbya sp. have their abundance associated with the months of lower water transparency, while Limnothrix planctonica and Alkalinema pantanalense are at the opposite end indicating a relationship with greater water transparency. These four species are adapted to low light environments, such as the Amazon River. However, in the trimester June-August, there is an increase in the Amazon water transparency reaching $32 \mathrm{~cm}$, which is still a dark environment although much better for photoautotrophs. A study on Limnothrix growth at different light intensities $\left(0,80,160,400,560 \mu \mathrm{E} \mathrm{m} 2 \mathrm{~s}^{-1}\right)$ showed an increase in cell concentrations under all light intensity, even without light, with glucose addition. The highest cell growth occurred at an intermediate light intensity ( $\left.160 \mu \mathrm{E} \mathrm{m} 2 \mathrm{~s}^{-1}\right)$ (Daniels 2016). In the study area, the L. planctonica population probably uses light most efficiently at the strength that it occurred from June to August.

As for nutrients, CCA associates L. planctonica and Alkalinema pantanalense with ammonia, which is the preferred nitrogen source of cyanobacteria (Oliver \& Ganf 2000; Grego et al. 2004; Bastos et al. 2005; Ceballos et al. 2006).

The present study consists of qualitative and quantitative research of the phytoplankton community in the catchment area for the water supply of Macapá municipality. The quantitative analysis shows that, in the evaluated environment, two species stand out in terms of density and relative abundance: Aulacoseira granulata and Limnothrix planctonica. Nevertheless, the biovolume values show the contribution of $A$. granulata as being the most representative in the study area. The paper also shows the environmental influence on phytoplankton species. The suspended solids are a natural condition that helps to control the phytoplankton density. On the other hand, ammonia is a common nutrient in domestic sewage that contributes to the phytoplankton increase and may be reduced with better investment in sanitation. These results demonstrate the biological and sanitary aspects of the species with the highest density and biomass (A. granulata and L. planctonica), which are more likely to influence water treatment in Macapá city.

\section{Acknowledgements}

We thank the Companhia de Água e Esgoto do Amapá, the Governo do Estado do Amapá, the Exército Brasileiro, the IBGE, and the Laboratório de Química e Saneamento da UNIFAP. We also thank Eleonora Cunha, Dinaldo Miranda and Sérgio Kléber for technical support. This study was translated and published with resources from the Support Program for National and International Academic Publications of the Universidade do Estado do Amapá.

\section{References}

Anagnostidis K, Komárek J. 1986. Modern approach to the classification system of cyanophytes: Chroococcales. Algological Studies 43: 157-226.

Anagnostidis K, Komárek J. 1988. Modern approach to the classification system of cyanophytes: Oscillatoriales. Algological Studies 50: 327-472.

APHA - American Public Health Association. 2010. American Water Works Association, Water Pollution Control Federation, \& Water Environment Federation. Standard methods for the examination of water and wastewater. Vol. 2. http://srjcstaff.santarosa.edu/ oraola/ Assets/APHA_SM_20.pdf.

APHA - American Public Health Association. 2012. American Water Works Association - Awwa; Water Pollution Control Federation - Wpcf. Standard methods for the examination of water and waste water. 22th. edn. Washington, DC, American Public Health Association.

AWWA. 2010. American Water Works Association. Algae: Source to Treatment. 1st. edn. Denver, American Water Works Association.

Bastos RB, Feitosa FAN, Muniz K. 2005. Variabilidade espaço-temporal da biomassa fitoplanctônica e hidrológica no estuário do rio Una (Pernambuco, Brasil). Tropical Oceanography 33: 1-18.

Bastos AM, Cunha AC, Bastos CMCB. 2009. Conflitos socioambientais em áreas de ressaca de Macapá e Santana: Modelagem de dispersão de esgoto doméstico na bacia do igarapé da fortaleza. In: XVIII Simpósio Brasileiro de Recursos Hídricos. Anais. Campo Grande/MS, Associação Brasileira de Recursos Hídricos. https://abrh.s3.sa-east-1.amazonaws. com/Sumarios/110/ec19014f3c02f309a98d1487331e8418_8cf5c30 4f97826315a3a7265ec3cec69.pdf.

Brasil J, Huszar VLM. 2011. O papel dos traços funcionais na ecologia do fitoplâncton continental. Oecologia Australis 15: 799-834.

Bernard C, Froscio S, Campbell R, Monis P, Humpage A, Fabbro L. 2011. Novel Toxic Effects Associated with a Tropical Limnothrix/ Geitlerinema-Like Cyanobacterium. Environmental Toxicology 26: 260-270.

Bicudo CEM, Menezes M. 2006. Gêneros de Algas de Águas Continentais do Brasil. São Carlos, Editora Rima.

Brandão CJ, Botelho MJC, Sato MIZ, Lamparelli MC. 2011. Guia nacional de coleta e preservação de amostras: água, sedimento, comunidades aquáticas e efluentes líquidos. São Paulo, CETESB.

Ceballos BSO, Azevedo SMFO, Bendate MMA. 2006. Fundamentos biológicos e ecológicos relacionados as cianobactérias. In: Pádua VL. (ed.) Contribuição ao estudo da remoção de cianobactérias e microcontaminantes orgânicos por meio de técnicas de tratamento de água para consumo humano. Rio de Janeiro, Associação Brasileira de Engenharia Sanitária e Ambiental - ABES. p. 23-81.

Cetesb. 2012. L5.303 Fitoplâncton de Água Doce: Métodos Qualitativo e Quantitativo. São Paulo, Companhia Ambiental do Estado de São Paulo - CETESB.

Chong S, Lee H, An KG. 2018. Predicting Taste and Odor Compounds in a Shallow Reservoir Using a Three-Dimensional Hydrodynamic Ecological Model. Water 10: 1396. doi:10.3390/w10101396

Chorus I, Bartram J. 1999. Toxic cyanobacteria in water: a guide to their public health consequences. Londres, E \& FN Spoon, on behalf of WHO.

Daniels O. 2016. Autecology, allelopathy, and toxicity of Limnothrix (strain AC0243): Multiple-organism studies using laboratory cultures. PhD Thesis, Central Queensland University, Rockhampton.

Di Bernardo L. 1995. Algas e suas influências na qualidade das águas e nas tecnologias de tratamento. Rio de Janeiro, Associação Brasileira de Engenharia Sanitária e Ambiental - ABES. 


\section{Natalina Borges da Silva, Luis Mauricio Abdon da Silva, Luís Roberto Takiyama, Mariano Araújo Bernardino Rocha and Elane Domênica Cunha de Oliveira}

Ewerts H, Swanepoel A, Preez HH. 2013. Efficacy of conventional drinking water treatment processes in removing problem-causing phytoplankton and associated organic compounds. Water Sa 39: 739-750.

Faustino SMM. 2006. O gênero Staurastrum (Zygnemaphyceae) no Estado de São Paulo: levantamento florístico. PhD Thesis, Universidade de São Paulo, São Paulo.

Furtado ALFF, Calijuri MDC, Lorenzi AS, Honda RY, Genuário DB, Fiore MF. 2009. Morphological and molecular characterization of cyanobacteria from a Brazilian facultative wastewater stabilization pond and evaluation of microcystin production. Hydrobiologia 627: 195-209.

Godinho LR. 2005. Gênero Staurodesmus (Zygnemaphyceae) no estado de São Paulo: levantamento florístico. MSc Thesis, Instituto de Botânica da Secretaria do Meio Ambiente do Estado de São Paulo, São Paulo.

Godinho LR. 2009. Família Scenedesmaceae (Chlorococcales, Chlorophyceae) no Estado de São Paulo: levantamento florístico. PhD Thesis, Instituto de Botânica da Secretaria do Meio Ambiente do Estado de São Paulo, São Paulo.

Grego CKS, Feitosa FAN, Honorato da Silva M, Flores Montes MJ. 2004. Distribuição espacial e sazonal da clorofila-a fitoplanctônica e hidrologia do estuário do rio Timbó (Paulista - PE). Tropical Oceanography, Paulista 32: 181-199.

Hillebrand H, Dürselen CD, Kirschtel D, Pollingher U, Zohary T. 1999. Biovolume calculation for pelagic and benthic microalgae. Journal of Phycology 35: 403-424.

Humpage A, Falconer I, Bernard C, Froscio S, Fabbro L. 2012. Toxicity of the cyanobacterium Limnothrix AC0243 to male Balb/c mice. Water Research 46: 1576-1583.

Joh G, Choi YS, Shin JK, Lee J. 2011 Problematic algae in the sedimentation and filtration process of water treatment plants. Journal of Water Supply: Research and Technology - AQUA 60: 219-230.

Junk WJ, Piedade MTF, Schöngart J, Cohn-Haft M, Adeney J, Wittmann F. 2011. A Classification of Major Naturally-Occurring Amazonian Lowland Wetlands. Wetlands 31: 623-640.

Junk WJ, Piedade MTF, Lourival R, et al. 2014. Brazilian wetlands: their definition, delineation, and classification for research, sustainable management, and protection. Aquatic Conservation: Marine and Freshwater Ecosystems 24: 5-22.

Komárek J, Anagnostidis K. 1999. Cyanoprokaryota, 1. Teil: Chroococcales. Süsswasserflora von Mitteleuropa 19: 1-549.

Lobo E, Leighton G. 1986. Estructuras comunitarias de las fitocenosis planctonicas de los sistemas de desembocaduras de rios y esteros de la zona central de Chile. Revista de Biologia Marinha y Oceonografía 22: 1-29.

Monteiro MDR, Melo NFAC, Alves MAMS, Paiva RS. 2009. Composição e distribuição do microfitoplâncton do rio Guamá no trecho entre Belém e São Miguel do Guamá, Pará, Brasil. Boletim do Museu Paraense Emílio Goeldi 4: 341-351.

Moreira-Filho H, Valente-Moreira IM, Trippia-Cecy II. 1974. Diatomáceas do Rio Guamá, Foz do rio - Belém - Estado do Pará. Leandra 3: 123-136.

Naselli-Flores L, Barone R. 2007. Pluriannual morphological variability of phytoplankton in a highly productive Mediterranean reservoir (Lake Arancio, Southwestern Sicily). Hydrobiologia 578: 87-95.

Niiyama Y, Tuji A, Takemoto K, Ichise S. 2016. Pseudanabaena foetida sp. nov. and P. subfoetida sp. nov. (Cyanophyta/Cyanobacteria) producing 2-methylisoborneol from Japan. Fottea 16: 1-11.

Nishimura PY, Moschini-Carlos V, Pompêo M. 2015. O estudo do fitoplâncton com base nos grupos funcionais: origens e um vislumbre sobre seu futuro. In: Pompêo M. (ed.) Grupos funcionais do fitoplâncton. Ecologia de reservatórios e interfaces. São Paulo, Universidade de São Paulo. p. 120-130.

Oksanen J. 2012. Constrained ordination: tutorial with R and vegan. R-packace Vegan 1: 10. http://www.mooreecology.com/ uploads/2/4/2/1/24213970/constrained_ordination.pdf.
Oliveira EDC, Castelo-Branco R, Silva L, et al. 2019a. First Detection of Microcystin-LR in the Amazon River at the Drinking Water Treatment Plant of the Municipality of Macapá, Brazil. Toxins 11: 269-288.

Oliveira EDC, Cunha AC, Silva NB, et al. 2019b. Morphological and molecular characterization of cyanobacterial isolates from the mouth of the Amazon River. Phytotaxa 387: 269-288.

Oliver RL, Ganf GG. 2000. Freshwater blooms. In: Whitton BA, Potts M. (eds.) The ecology of cyanobacteria. Dordrecht, Kluwer Academic Publishers. p. 149-194.

Oliver SL, Ribeiro H. 2014. Variabilidade climática e qualidade da água do Reservatório Guarapiranga. Estudos Avançados 28: 95-128.

Otten TG, Graham JL, Harris TD, Drehera TW. 2016. Elucidation of Taste- and Odor-Producing Bacteria and Toxigenic Cyanobacteria in a Midwestern Drinking Water Supply Reservoir by Shotgun Metagenomic Analysis. Applied and Environmental Microbiology. 82: 5410-5420.

Padisák J, Soróczki-Pintér É, Rezner Z. 2003. Sinking properties of some phytoplankton shapes and therelation of form resistance to morphological diversity of plankton -An experimental study. Hydrobiologia 500: 243-257.

Padisák J, Crossetti LO, Naselli-Flores L. 2009. Use and misuse in the application of the phytoplankton functional classification: a critical review with updates. Hydrobiologia 621: 1-19.

Paiva RS, Eskinazi-Leça E, Passavante JZO, Silva-Cunha MGG, Melo NFAC. 2006. Considerações ecológicas sobre o fitoplâncton da baía do Guajará e foz do rio Guamá, Pará, Brasil. Boletim do Museu Paraense Emílio Goeldi 1: 133-146.

Prescott GW, Croasdle HT, Vinyard WC. 1977. A synopsis of North American desmids. Part II. Section 2. Lincoln, NE, University of Nebraska Press.

Prescott GW, Bicudo CM, Vinyard WC. 1982. A synopsis of North American desmids. Part II. Section 4. Lincoln, NE, University of Nebraska Press.

R Development Core Team. 2017. A Language and Environment for Statistical Computing. http://www.R-project.org. 10 Nov. 2017.

Reynolds CS, Descy JP, Padisák J. 1994. Are phytoplankton dynamics in rivers so different from those in shallow lakes? Hydrobiologia 285: 1-7.

Reynolds CS, Huszar V, Kruk C, Naselli-Flores L, Melo S. 2002. Towards a functional classification of the freshwater phytoplankton. Journal of Plankton Research 24: 417-428.

Reynolds CS. 2006. The Ecology of Phytoplankton (Ecology, Biodiversity, and Conservation). Cambridge, Cambridge University Press.

Sant'Anna CL, Azevedo MTP, Agujaro LF, Carvalho MC, Carvalho LR, Souza RCR. 2006. Manual Ilustrado para Identificação e Contagem de Cianobactérias Planctônicas de Águas Continentais Brasileiras. Rio de Janeiro, Editora Rima.

Silva NB, Lopes JO, Brito JDM, et al. 2018. Diagnóstico da qualidade da água em áreas utilizadas pela bubalinocultura no Baixo Araguari, Amapá, Brasil. Biota Amazônia 8: 22-28.

Sioli H. 1984. Hydrochemistry and Geology in the Brazilian Amazon region. Amazoniana 1: 74-83.

Ter Braak CJF, Verdonschot PFM. 1995. Canonical correspondence analysis and related multivariate methods in aquatic ecology. Aquatic Sciences 57: 255-289.

Utermöhl H. 1958. Zur vervollkommnung der quantitativen phytoplanktonmethodik: Mit 1 Tabelle und 15 abbildungen im Text und auf 1 Tafel. Internationale Vereinigung für Theoretische und Angewandte Limnologie: Mitteilungen 9: 1-38.

Watson SB, Caldwell G, Pohnert G. 2009. Fatty acids and oxylipins as semiochemicals. In: Arts M, Brett M, Kainz M. (eds.) Lipids in Aquatic Ecosystems. New York, Springer. p. 65-92.

Watson S, Jüttner F. 2019. Biological production of taste and odour compounds. In: Lin TF, Watson S, Dietrich AM, Suffet IHM. (eds.) Taste and Odour in Source and Drinking Water: Causes, Controls, and Consequences. London, UK, IWApublishing. p. 63-112.

Whan PM. 2015. Investigation of a novel toxin produced by a Limnothrix cyanobacteria. PhD Thesis, University of Adelaide, Adelaide. 